\title{
III.
}
The Hydroid Zoophytes of the "Willem Barents" Expedition, 1881
$\mathrm{BY}$

D'ARCY W. THOMPSON, B. A.

Trinity College, Cambridge. 


\section{The Hydroid Zooplytes of the „Willem Barents” Expedition, 1881.}

The collection of Hydroidea obtained by this Expedition, was forwarded to me for examination in the summer of 1882 , by Dr. MAX WEBER, of Amsterdam. I have found no new species in it, - a natural result of the number of Scandinavian and Arctic Hydroids that have been made known to us in late years, by MM. M. and.G. O. Sars, Allman, Hincks, Metschnikoff and others. But the present collection contains several species hitherto rare, it extends greatly the range of many that have formerly been reported from only one or two localities, and it contains also several well marked and peculiar varieties. It includes altogether 24 species from 12 stations, from various depths down to 170 fathoms. The annexed table gives the names of the species with the stations and depths at which they were found.

The most prominent and luxuriant species are Sertularia gigantea, and Lafoëa fruticosa; - of which the former is common everywhere in shallow, the latter in deep water; most of the species are large and strong in comparison with specimens from farther south.

Of the twenty-four species, tifteen are common British forms; of the rest, I have referred two more to British species, but they differ from our common type, and form well-marked varieties.

There remain seven northern species, whose distribution may be summarized as follows:

Sertularia albimaris ; White sea, Metschnikoff; Spitzbergen, (?) Allman; off the Petschora, Will. Bar. Exp.

Sertularella gigantea; Iceland, Hrncks; Greenland (?) SARs; Alaska (?) CuARke; Vardö, Matotschkin Scharr, Petschora, Will. Bar. Exp.

L a f o ë a g r a nd is; Lofoten; G. O. SArs; Iceland, HIncks; Alaska, Crarke; Barents Sea, W ill. Bar. Exp.

Lafoèa capillaris; Christianiafjord, G. O. SARs; Barents Sea, Will. Bar. Exp.

Cal y c ella quadridentat a; Christianiafjord, Vadsö, SArs; Barents Sea, Will. Bar. Exp.

Lafoêina tenuis;. Christiansund, Lofoten, SArs; Iceland, Hincks; Petschora, Will. Bar. Exp.

This summary indicates a very wide arctic or cicumpolar distribution for most if not all of the above forms. 


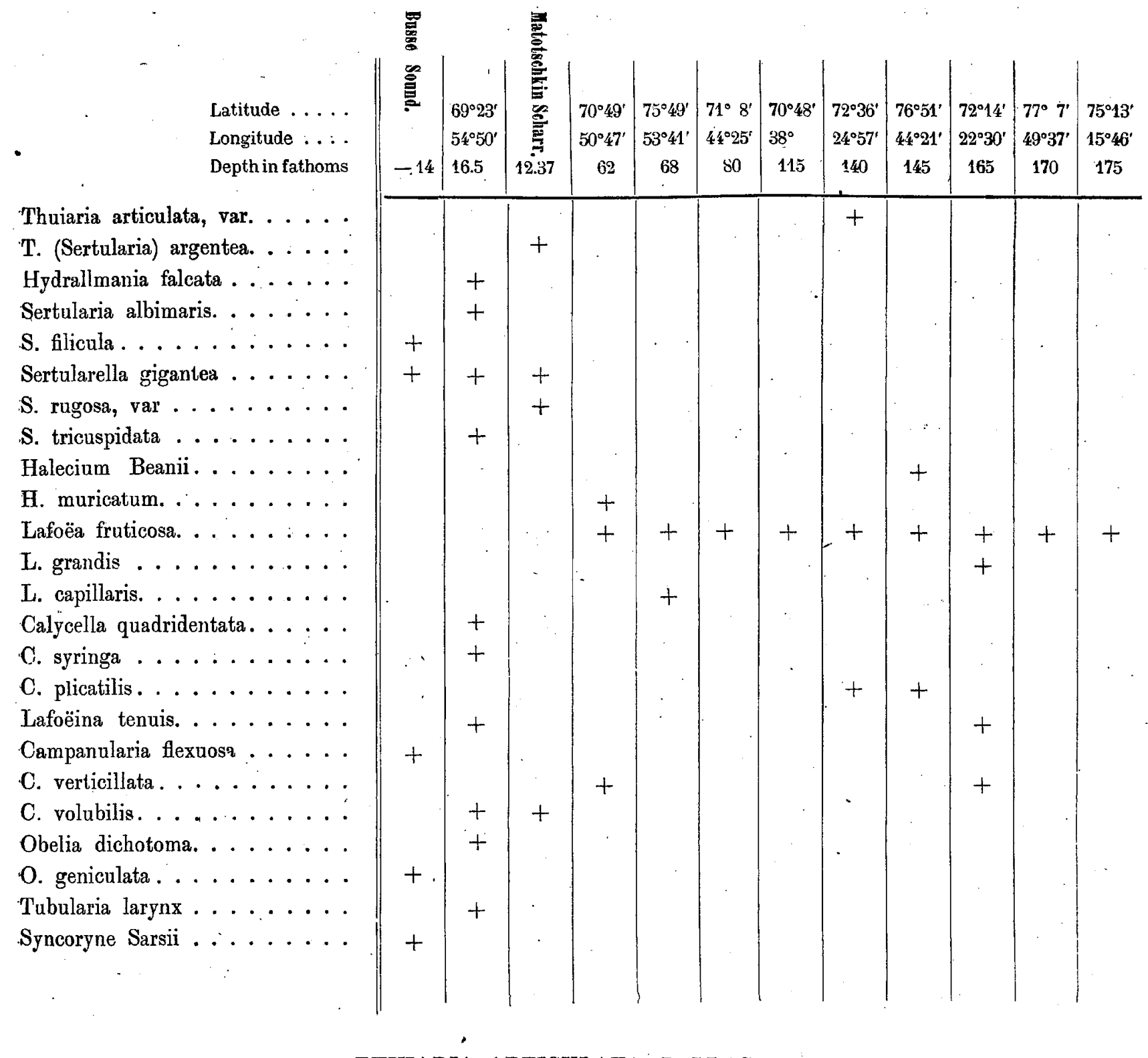

THUIARIA ARTICULATA, PALLAS: var.

Plate I. fig. 14. 15.

A single small specimen, which I ascribe to this species, occurs in the collection. It is about three inches high, and destitute of gonangia. It differs from the common from of T. ar tic ulat a in the complete immersion of the hydrothecaê, whose orifices do not project at all, but lie flush with the sides of the stem and branches; they do not differ in shape or size from those of the common form of the species. The branches are thinner and more delicate than in the common form; but the specimen does not differ so much in appearance from the type-form, as, for instance, the Shetland variety mentioned by Mr. Hincks (Brit. Hydr. Zooph., p. 278, pl. 60); I inclined at first to think the specimen a young example of T. I a xa, Allman ${ }^{1}$ ), but the hydrothecaê differ in shape from those of the latter species in ALLman's figure, being. straighter, and square, not rounded, at the base.

Loc. lat. $72^{\circ} 99^{\prime} \mathrm{N}, 25^{\circ} 58^{\prime} \mathrm{E}$, rather more than a hundred miles north of the North Cape; depth, 140 fathoms.

1) Hydr. of Porcupine Exp., Tr. Zool. Soc. Lond., VIII, p. 472, 1874. 
THULARIA (SERTULARIA) ARGENTEA, ELLIS.

I follow Allman ${ }^{1}$ ) in relegating this species to Thuiaria. One or two specimens, with gonangia, occur in the collection. They were got in 10 fathoms water, in Matthew's Straits (Matotschkin Schaar), Novaya Zemlya.

This species was found by $\mathrm{S}_{\mathrm{ARS}}{ }^{2}$ ), near the North Cape, while its close ally ' $\mathrm{T}$. (S e r t.) cupressina does not occur in SARs' list as a Norwegian hydroid at all. The latter species, however, has been recorded by Hincks ${ }^{3}$ ) from Barents Sea.

\section{HYDRALIMANIA FALCATA, L.}

Fine specimens of this species were got in 16.5 fathoms, near the mouth of the Petschora.

SERTULARIA ALBIMARIS, METSCHNIKOFF. (Ann. and Mag. of Nat. Hist. ser. 5, vol. I, p.331, 1878).

Plate I. fig. 1, 2, 3.

S. ar ctica, Allman (?)

Several specimens occur from the prolific locality near the mouth of the Petschora (16 fathoms). They undoubtedly belong to METschnikoff's species, though the curious hydrorhiza, on which MeTSCHNIKOFF rests much importance, is preserved in none of them. But they present this very curious and anomalous character, not mentioned by METSCHNIKofr, that the branches are frequently prolonged into long tendril-like shoots, bare of hydrothecaê. These tendrils have usually one joint: at the base, but no more, and they very much resemble the tendrils of $\mathrm{Th}$ u i a ria persocia lis, a species described by Aluman ${ }^{4}$ ), from Natal. How they end, and whether they serve for attachment, I do not know.

The hydrothecaê very much resemble those of S. a rctica, ALLMaN ${ }^{5}$ ), from Spitzbergen; and the two species are probably identical, in which case Allwas's name has the priority. But the hydrothecaê in AlLMax's figure are considerably longer than those in any of my specinens. The gonangia, which might have decided the point, are wanting both in my specimens and in METSCHNIKOFF's type.

SARs' S. tene ra, of which I have examined specimens from the Vega collection, is distinct. from this species.

\section{SERTULARIA FILICULA, ELLIS AND SOLANDER.}

A single well-marked specimen (without gonangia) was got in shallow water in Busse Sound.

$$
\text { SERTULARELLA GIGANTEA, METSCHNIKOFF (loc. cit.) }
$$

Plate I. fig. $4,5,6,8$.

S. polyzonias, var. robusta, Sars. (Nyt. Mag. for Naturvidensk. 1857. p. 163).

S. polyzonias, var. giga n tea, Hincks. (Ann. and Mag., Ser. 4, vol. XIII, p. 15l, 1874). S. quadricornis. Hincks (Ibid., Ser. 5, vol. VI, p. 277. 1880).

There is some confusion in regard to the large northern Sertularellaê, allied to S. p ol y z o nias The present collection contains a number of specimens, whose calycles show very considerable limits of variation. After an examination of thse. I am inclined to think that the above three forms: are all referable to. one species, the $\mathrm{S}$. $\mathrm{g}$ ig a $\mathrm{n}$ t e a of MeTschniкorf.

1) Proc. Linn. Soc., XII, p. 267, 1875.

2) Vidensk. Selsk. Forhandl., 1873.

8) Ann. and Mag. of Nat. Hist., ser. 5, vol. VI, p. 269. 1880.

4) Proc. Linn. Soc. Lond., vol. XIII, 1875.

5) Ibidem. 
HrNcks figured specimens from Iceland, under the name of S. p o l y z o n i a s, var. gi i a n t e a, and Metschnikofr figured others from Siberia, which he identified with HrNcks zoophyte, under the name of S. giga ntea. Metschnikoff's specimens were marked by the existence of a number of ledges below the mouths of the hydrothecaê, which do not occur in Hincks' figures; but Metschnikoff is careful to state that they are present only in adult individuals.

In a later paper (October, 1880), HINCKs describes another large arctic Sertularella (from Barents Sea) under the name of S. quadricornis; and states his belief that his S. polyzonias, var. gigantea, and MetschniKoff's S. gigante a are really distinct, though the latter and S. quadricornis may be identical. Now I have no hesitation in saying that the former two belong to one and the same form, while the last probably does so, though not quite certainly. The ledges below the hydrothecal orifices are, as MEISCHNIKoFf stated, only present in old individuals; in my plate, figs. 4 and 8 are both taken from the same colony. There is also much variation in the extent to which the hydrothecaê are immersed: sometimes they are almost completely free and sessile. as in fig. 6, which is almost the exact counterpart of HincKs' figure (loc. cit., pl. VII, 1874); in other cases, in the same colony or even on the same shoot, they are attached for half their length, as in fig. 4. But $I$ have seen no specimens that can be called intermediate between this arctic form and the typical S. polyzonias. I reproduce Hincks' figure of S. quadricornis for comparison; it only differs from those under consideration in the marked constriction in the middle of the hydrothecaê. I have searched all my specimens in vain for gonangia, to compare with those figured by Hincks in S. quadricornis.

S. giga ntea occurs in the collection from all three stations in which hydroids were obtained in shallow water: viz., at Bussö Sound, Vardö, in Matotschkin Scharr (10 fathoms), and near the mouth of the Petschora (16.5 fathoms).

SERTULARELLA RUGOSA, L. var.

Plate I. fig. $10,11,12,13$.

This zoophyte is very remarkable for the long, bare, tendril-like shoots into which its stems are prolonged, resembling very much the tendrils described above in the case of Sertularia a J.bimaris. The calycles are distinctly larger than those of British specimens of S. r u gos a, the neck is more distinct, and the teeth longer. Nevertheless, they can only be classed as a single species. Defective nutrition or low temperature may perhaps account for this production of bare shoots in two different northern varieties.

L o c ality. Matotschkin Scharr, 10 fathoms.

$$
\text { SERTULARELIA TRICUSPIDATA, ALDER. }
$$

Strong and robust specimens of this species were got abundantly in 16.5 fathoms, at the station near the mouth of the Petschora. The specimens have no gonangia. The species does not occur in SARS' Norwegian list, but is reported from Iceland by Hincks.

\section{HALECIUM BEANII, JOHNSTON.}

A specimen, without gonangia, occurs from a depth of 145 fathoms in lat. $76^{\circ} 51^{\prime}$, long. 44० $21^{\prime}$.

$$
\text { HALECIUM MURICATUM, ELLIS AND SOLANDER. }
$$

$\mathrm{A}^{\prime}$ good specimen, bearing gonangia, was got in lat. $70^{\circ} 49^{\prime} \mathrm{N}$., long. $50^{\circ} 47^{\prime}$ E., at a depth of 62 fathoms. 
LAFOËA GRANDIS, HINCKS. (Ann. and Mag., ser. 4, vol. XIII, p. 148, 1874).

L a foë a fruticosa, G. O. Sars. (Vid. Selsk. Forh., 1873); not M. Sars, ibid., 1862.

L. fruticosa, S. F. Clarke (Exploration of Alaska. 1876).

Plate I. fig. 16.

The task of identifying the varions species of $\mathrm{L}$ a f o ë a, especially the erect, shrubby forms, of which this is one, is rendered somewhat difficult by the want of exact measurements of the calycles, or of comparative series of figures, drawn to scale.

Mr Hncks (loc. cit.) seems however to have cleared. up the synonymy of this species satisfactorily, showing it to be identical with G: O. SARS' but distinct from M. SARS' L. fruticosa.

This species is a well-marked one, the calycles being very much larger than those of its allies, and possessing a characteristic campanulate shape, by which the species is easily to be recognized in G. O. SARs' figures.

The calycles are about $8-9 \mathrm{~mm}$. long.

This species occurred sparingly in lat. $76^{\circ} 51^{\prime}$ N., long. $44^{\circ} 21$, E. (145 fathoms).

LAFOËA FRUTICOSA, M. SARS. (Tid. Selsk. Frork., 1864).

Campan u.laria gracilli in a, Alder. ('Trans. Tyneside Field Club, III, p. 129, 1857).

Laf ö̈a gracillima, G. O. Sars. (Vid. Selsk. Forh., 1873).

L. gracillima, S. F. Clarke. (Exploration of Alaska, 1876).

Plate 1. fig. 17, 18.

This species occurred very abundantly in several localities : lat. $72 \circ 14 \mathrm{f}^{\prime} \mathrm{N}$., long. $22 \circ 30^{\prime} \mathrm{E}$., (165 fathoms); lat. $75^{\circ} 49^{\prime} \mathrm{N}$, long $53^{\circ} 4 \mathrm{l}^{\prime}$ E., (68 fathoms); lat. $76^{\circ} 5 \mathrm{l}^{\prime} \mathrm{N}$, long. $44^{\circ} 2 \mathrm{l}^{\prime} \mathrm{E}$, (145 fathoms).

The dimensions of the calycles vary within small limits; their length is about $5-6 \mathrm{~mm}$.

A small specimen (fig. 18) from lat. $72^{\circ} 36^{\prime}$ N., long. $24^{\circ} 57^{\prime}$ E., (140 fathoms) is rather strikingly different from the rest, the hydrothecaê being considerably smaller $(4 \mathrm{~mm}$.) and without amy trace of widening at the mouth. It is intermediate in appearance between L. fruticos a and l. capillaris, and may belong to a distinct species. But for the present I prefer merely to record and figure it.

LAFOËA CAPILLARIS, G. O. SARS. (Vid. Selsk. Forh., 1873.)

Plate I. fig. 19.

The slenderness and length of the hydrothecaê render this species unwistakable.

It occurred in lat. $75^{\circ} 49^{\prime}$. N., long. $53^{\circ} 41^{\prime}$ E. (68 fathoins). SARS found it in the Christianiafjord, at a depth of 50-60 fathoms. Though scarce, it is therefore very widely distributed. The calycles are about $8 \mathrm{~mm}$. long.

CALYCELLA QUADRIDENTATA, HINCKS (Ann. and Mag. of Nat. Hist., ser. 4, val. XIII,p. 149, 1874).

Plate I. fig. 20.

This very pretty species, described from Reykiavik (100 fathoms) by Hincks, was got in 16.5 fathoms near the mouth of the Petschora.

The calycles vary somewhat in shape, some being considerably longer and thinner than others. They are ahout 4 to $5 \mathrm{~mm}$. long, and considerably wider than those of C. sy ringa. 


\section{CALYCELLA SYRINGA, L.}

Plate I. fig. 21.

This species occurs from several stations, including that in lat. $72^{\circ} 14^{\prime} \mathrm{N}$., long. $22^{\circ} 30^{\prime} \mathrm{E}$., where it is parasitic on Lafoë ina tenuis at a depth of 165 fathoms. Hincks has recorded it from a depth of 100 fathoms, off Iceland.

CALYCELLA (LAFOËA) PLICATILIS, M. SARS (Vidensk. Forhandl., 1862).

This remarkable species was got abundantly at a depth of 145 fathoms in lat. $76^{\circ} 51^{\prime} \mathrm{N}$., long. 44.20 E. According to G. O. SARS, it ranges from 20 to $200^{\circ}$ fathoms.

I.AFOËINA TENUIS, M. SARS (G. O. Sars, Vidensk. Forhandl., 1873).

This species was found by SARS at various depths ranging from 50 to 300 fathoms. In the present collection it occurs from 16 fathoms, near the Petschora, to 165 fathoms, north of the North Cape.

CAMPANULARIA FLEXUOSA, HINCKS.

This exclusively littoral species was got at Vardö.

CAMPANULARIA VERTICILLATA, L.

Some specimens occur from the unusual depth "of 165 fathoms, in lat. $72^{\circ} 14^{\prime}$, north of the North Cape.

\section{CAMPANULARIA VOLUBILIS, L.}

Common near the Petschora, in $\mathbf{1 6 . 5}$ fathoms, and in Matotschkin Scharr, 34 fathoms.

OBELIA GENICULATA, L

Very abundant specimens, on La in in a r i a, from Vardö.

OBELIA DICHOTOMA, L.

Several small pieces occur among the numerous hydroids from the station near the mouth of the Petschora (16.5 fathoms). 'The species does not occur in SARs' Norwegian list.

TUBULARIA LARYNX, ELLIS AND SOLANDER.

The tubes of a small species of Tubularia occur among the material from near the mouth of the: Petschora, in 16.5 fathoms. They have all the habit of this species, to which $I$ have no doubt they belong, but they are very slightly and irregularly ringed, in a manner more like 'I. c o r o n a t a.

\section{SYNCORYNE SARSII, LOVÉN.}

Very abundant specimens from shallow water in Busse Sound, Vardö. 


\section{P A P E R S}

ON

\section{Seandinavian and Aretic Hydroids. $\left.{ }^{1}\right)$}

Alluman, G. J. Hydroida collected during the Expedition of H. M. S. Poreupine. Trans. Zool. Soc. vol. VIII. pp. $469-482.1874$.

, New genera and species of Hydroida. Journ. Linn. Soc. vol. XII, 1874.

Clarke, S. P. JR. Report on the Hydroids of Alaska. Smithsonian Institute, Washington, 1876, also Proc. Acad. Philadelphia, 1877.

Hincks, T. Norwegian Hydroida from Dèp water. Ann. and Mag. of Nat. Hist. 4, XIII, pp. 125-137. 1874 .

$\longrightarrow$ Deep water Hydroida from Iceland. ibid. pp. 146-15̆4.

$\therefore$ New Hydroida from Barents Sea, ibid. 5, VI, 1880.

- Hydroids of Barents Sea, in D'Urban's Zool. of Barents Sea, ibid..

Lürken, Chr. List of the Acalephaê and Hydrozoa of Greenland. A rctic-lianual, ed. by Prof. Rupert Jones; London. 1875.

Mereschkowsky, C. On a new Genus of Hydroids from the White Sea (Monobrachiu m). Ann. and Mag. of Nat. Hist.. 4, XX, pp. 220-229, 1877.

New Hydroida from Kamtschatka, etc. Ann. and Mag. of Nat. Hist., 5 II. pp. 433-451. 1878. Studies on the Hydroida, ibid. 5. I. 1878.

SARs, G. O. Bidrag til Kundskaben om Norges Hydroider. Vid.-Selsk. For h. 1873.

STORM, V. K. Norske Vid. Selsk. Skrift., 1881.

Winther, G. De i Danmark og dets Nordlige Bilande fundne Hydroide. Zoophyter. Copenhagen, 1876.

1) Not including those named in Hincks' list., Brit. Hydr. Zooph. Appendix.

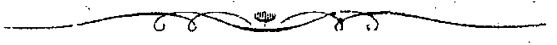




\section{F I G U R E S.}

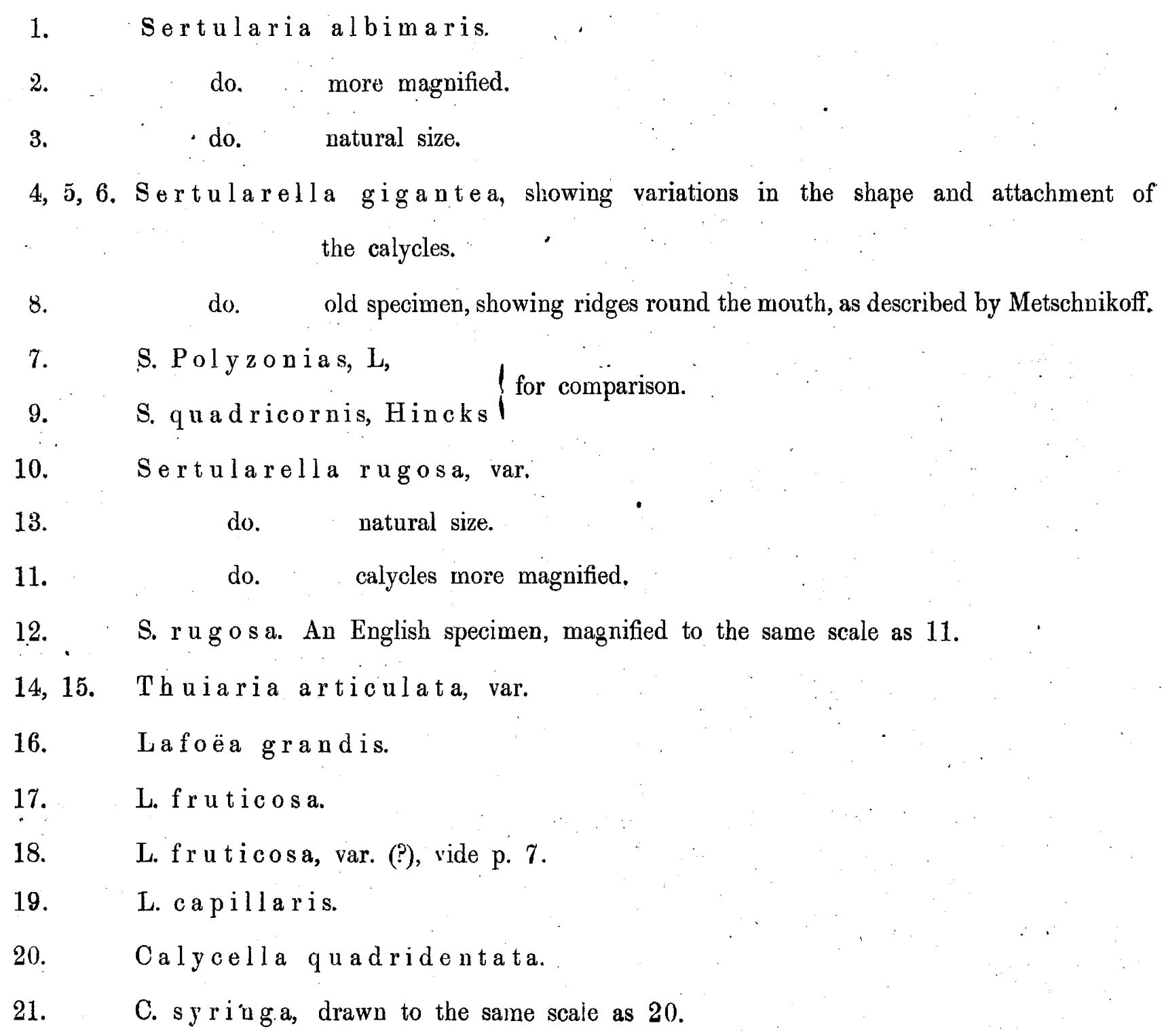




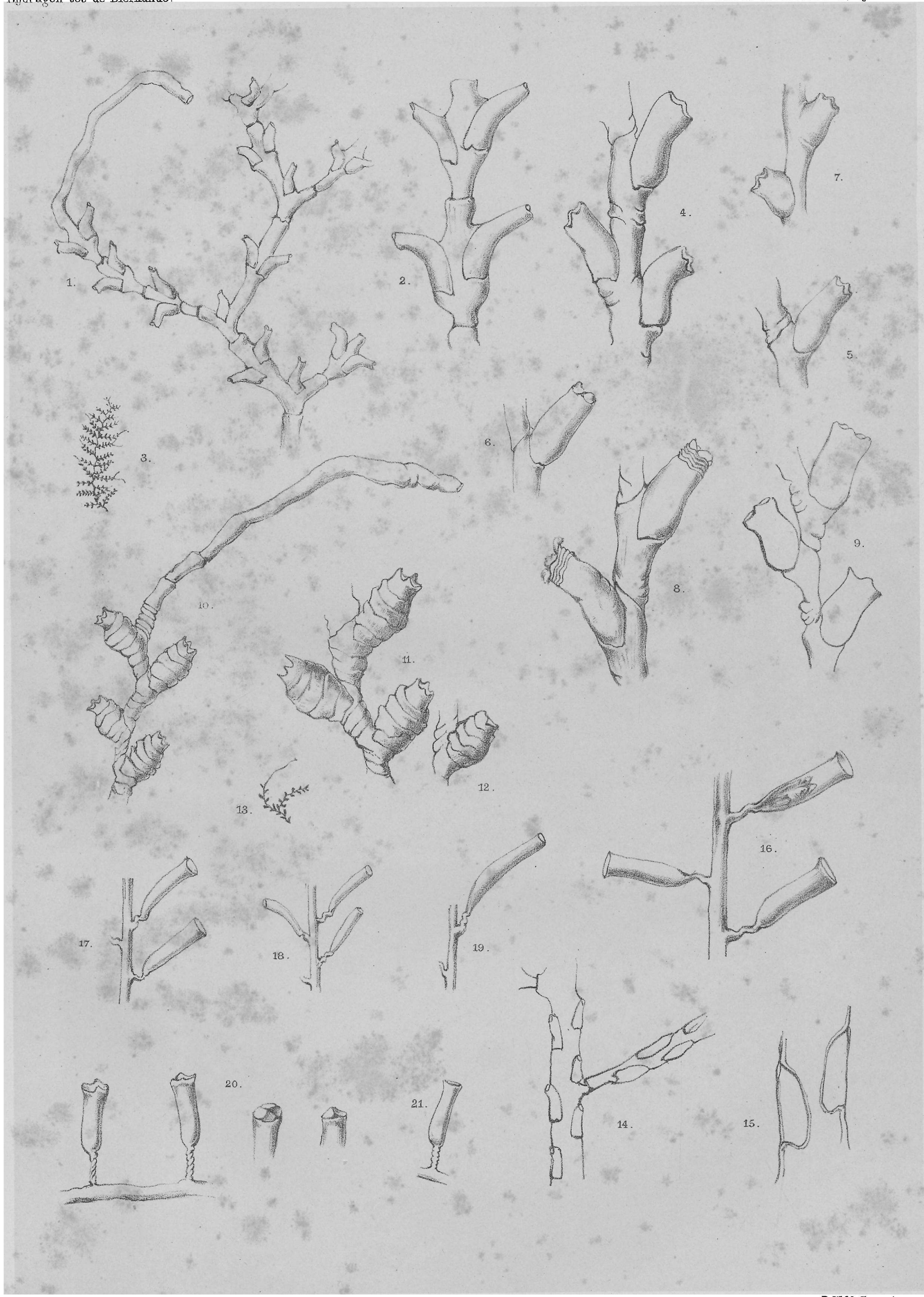

